\title{
A case study of the planktonic communities in two hydrologically different oxbow lakes, Vistula River, Central Poland
}

\author{
Ewa A. DEMBOWSKA, Paweł NAPIÓRKOWSKI \\ Nicolaus Copernicus University, Faculty of Biology and Environmental Protection, Department of Hydrobiology, Lwowska 1, 87-100 \\ Toruń, Poland \\ *Corresponding author: pnapiork@umk.pl
}

\begin{abstract}
Floodplain lakes are important elements of landscapes with large rivers. In this study we compared planktonic communities of two oxbow lakes of the Vistula River. We investigated how the inflow of the river's water affected their physicochemical and biological conditions including water temperature, water transparency, oxygen concentration, and macrophyte coverage of the bottom. These parameters in turn affected plankton community. The average phytoplankton abundance in the isolated lake was over two times lower than in the lake connected to the river. Cryptophyta dominated in the phytoplankton community in the isolated lake and diatoms - in the lake supplied with water from the river. The average abundance of zooplankton in the isolated lake was more than twice as high as that in the lake which was connected to the river. The first lake proved to be more attractive for zooplankton due to its stable living conditions (similar to the conditions observed in ponds), higher temperature in summer, and nutrient availability due to the high abundance of small phytoplankton. The results of our research indicate that species composition, plankton abundance, and Chl-a concentration depended on whether there was water exchange between the particular lake and the Vistula River. Hydrological conditions shaped the relationships between the components of the biota.
\end{abstract}

Key words: Cryptophyta, diatoms, floodplain lakes, hydrology, Rotifera, wetlands.

Received: July 2014. Accepted: December 2014.

\section{INTRODUCTION}

Floodplain lakes are important elements of landscapes with large rivers. However, improper management of natural resources leads to degradation and extinction of these ecosystems, which are known for high biodiversity and ecological value (Hillbricht-Ilkowska, 1999; Redford and Richter, 1999; Tockner et al. 2009).

Floodplain lakes play a significant role in a river system:

- They constitute a geochemical barrier (reducing the inflow of nutrients and contaminants to the river) (Lake and Bond, 2007; Dembowska and Napiórkowski, 2012).

- They provide shelter for animals after river floods (Meschiatti et al., 2000; Paira and Drago, 2007)

- They constitute a habitat for aquatic animals (Junk et al., 1989; Shiel et al., 1998).

Oxbow lakes can be seen as places for smooth transition from flowing to stagnant waters (Baranyi et al., 2002; Starmach et al., 1976). According to Jezierska-Madziar (2005), oxbow lakes are formed in two ways: naturally and artificially (regulation of a riverbed). Natural oxbow lake are cut off from the main stem of the river. Because of their small surface and depth they easily undergo succession. During the process they are overgrown with water plants, become shallower, and finally disappear. Ar- tificial oxbow lakes are formed by human hydrological activity. Lakes of this type are often connected to the river on one side. With the right level of water in the river, the connection offers a water exchange.

The significance of plankton in the ecosystems of floodplain lakes was described by Salbrechter (1998), Keckeis et al. (2003), Gumiri et al. (2005), Napiórkowski (2009), Obolewski (2011), and Dembowska et al. (2012). Anderson and Bonecker (2004) as well as Schöll (2009) point out that plankton communities in floodplain lakes are determined primarily by two things: i) whether they are connected or not to the river; and ii) whether water inflow causes any disturbances.

We assume that irregular inflows of water from the river destabilise conditions in oxbow lakes including water transparency and temperature and inhibit macrophyte growth. All these changes affect plankton community. We put forward a hypothesis that phytoplankton should be more abundant and diverse in the oxbow lake connected as compared to one isolated from a river. The inflow of the river's water into this lake inhibits the development of submerged vegetation and increases phytoplankton biomass. It also provides nutrients and intensifies nutrients' release from the bottom sediments of the lake (Hein et al., 2004; Kasten, 2003; Grabowska et al., 2014). 
Macrophytes in the lake isolated from the river can suppress phytoplankton development through allelopathic influence, shading water and the bottom, and competing for food (Scheffer, 1998). Numerous studies confirm a relationship between vascular vegetation and planktonic algae (Gross, 2003; Gross et al., 2007; Lau and Lane, 2002; Mulderij et al., 2007).

On the other hand, we expected that zooplanktonic community in the lake connected with the river should be less abundant and less diverse than in the isolated lake. Thomaz et al. (2007) noted that zooplankton diversity decreases due to the homogenizing effect in floodplain lakes, flooded by water from rivers. When the water is stagnant macrophyte biomass in the lake increases. Macrophytes offer perfect conditions for zooplankton. They provide shelter for zooplankton against planktivorous fish and invertebrate predators (Lauridsen et al., 1996). Moreover, zooplankton inhabiting macrophyte stands can feed on algae found between plant stems, periphyton, protozoans, bacteria and detritus (Kuczyńska-Kippen and Nagengast, 2006). Basu et al. (2000) examining the fluvial lakes of St Lawrence River, observed a 9-fold higher zooplankton biomass within dense macrophyte stands than in open water or sparsely vegetated areas.

In view of the absence of information on plankton in floodplain lakes, we evaluated the taxonomic composition and abundance of planktonic communities (phytoplankton and zooplankton) in two oxbow lakes associated with the Vistula River. One of the lakes is periodically connected with the river, and the second is totally isolated from the riverbed. Our specific objective was to determine the influence of the water from the Vistula River on these two habitats.

\section{METHODS}

\section{Study area}

With the length of $1068 \mathrm{~km}$ The Vistula River is the longest river in Poland and has the second largest (after Neva) catchment area of the Baltic Sea $\left(194,000 \mathrm{~km}^{2}\right)$. The Vistula has all the characteristics of a lowland river over most of its course. In the $19^{\text {th }}$ century, the river was regulated between $718 \mathrm{~km}$ and the mouth $(1068 \mathrm{~km})$. Despite human interference (changing the river's flow) and advancing degradation, the river and the valley represent an extremely valuable natural environment (Kentzer et al., 2010).

The first floodplain terrace has a number of oxbow lakes which are the remains of the backwaters of the river and are periodically flooded (during major floods only). There are also artificial oxbow lakes in the river valley. The study was conducted on two different floodplain lakes, natural and artificial, the latter created after the flood embankments had been constructed during river regulation at the beginning of the $19^{\text {th }}$ century (Makowski, 1998).

The studied lakes (Fig. 1) are situated in the valley of the Lower Vistula, within the city of Torun, between 734 and $738 \mathrm{~km}$ of the river's course. Site $1\left(53^{\circ} 01^{\prime} \mathrm{N} ; 18^{\circ} 39^{\prime} \mathrm{E}\right)$ includes the floodplain lake of the Vistula River located on the $734^{\text {th }} \mathrm{km}$ of the river's course. It is a meandering part of the river, which is being overgrown by vegetation and which developed, as many others, due to the Vistula River regulation. It is a small water body without direct surface contact with the water of the Vistula River. In the floodplain lake, the following species of macrophytes occur: yellow pond-lily (Nuphar lutea (L.) Sm.), rigid hornwort (Ceratophyllum demersum L.), and star duckweed (Lemna trisulca L.). The morphometric characteristics of the oxbow lake are: a surface area of 2.5 ha maximum length of $220 \mathrm{~m}$, maximum width of $40 \mathrm{~m}$, and a maximum depth of $2.0 \mathrm{~m}$. Site $2\left(53^{\circ} 00^{\prime} \mathrm{N} ; 18^{\circ} 33^{\prime} \mathrm{E}\right)$ includes the floodplain lake of the Vistula River, situated at the $738^{\text {th }} \mathrm{km}$ of the river's course. This oxbow lake developed as a result of the Vistula River regulation. It is relatively shallow, young, and usually connected to the Vistula River (with the average water level in the river). In the oxbow lake, the following species of

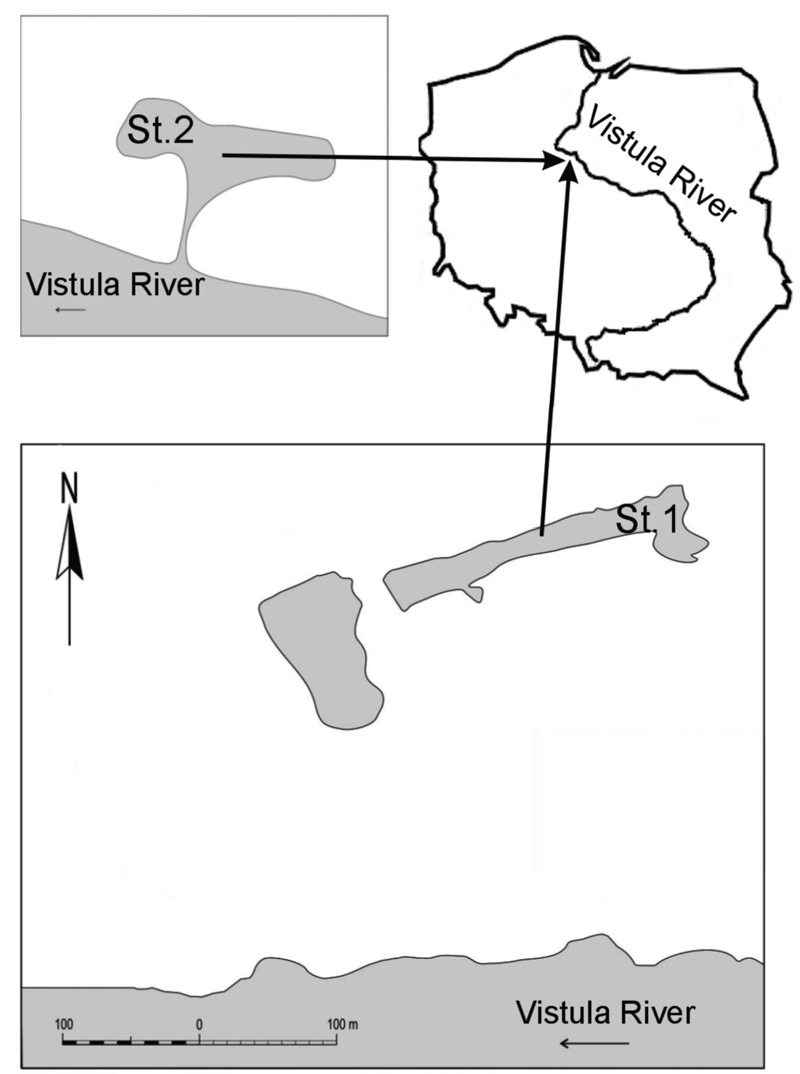

Fig. 1. Location of the sampling sites in floodplain lakes (Poland). 
macrophytes occur: common hornwort (Ceratophyllum demersum), arrowhead (Sagittaria sagittifolia L.) which grows on the shores of the oxbow lake, but when the water level is very low it forms peculiar islands in the middle of the oxbow lake, Canadian waterweed (Elodea canadiensis Michx.), pondweed species (Potamogeton sp.), and water milfoil sp. (Myriophyllum sp.). The morphometric characteristics of the floodplain lake are: surface area $1.0 \mathrm{ha}$, maximum length $160 \mathrm{~m}$, maximum width $100 \mathrm{~m}$, degree of connection with the Vistula River from 0 to $30 \mathrm{~m}$. The maximum depth depends on the water level in the river (from 60 to $160 \mathrm{~cm}$ ).

The value of TP at summer in 2008 at the site 1 amounted $0.16 \mathrm{mg} \mathrm{L}^{-1}$ and $0.36 \mathrm{mg} \mathrm{L}^{-1}$ at site 2 . The concentration of mineral forms of nitrogen and phosphorus amounted $0.134 \mathrm{mg} \mathrm{L}^{-1}\left(\mathrm{~N}-\mathrm{NO}_{3}\right), 0.068 \mathrm{mg} \mathrm{L}^{-1}\left(\mathrm{P}^{-1} \mathrm{PO}_{4}\right)$ for site 1; and $0.208 \mathrm{mg} \mathrm{L}^{-1}\left(\mathrm{~N}^{\left.-\mathrm{NO}_{3}\right)}, 0.067 \mathrm{mg} \mathrm{L}^{-1}(\mathrm{P}-\right.$ $\mathrm{PO}_{4}$ ) for site 2 .

\section{Sampling methodology}

Water samples were collected twice a month between April and September, 2008. All phytoplankton and zooplankton samples were collected at a depth of ca. $0.5 \mathrm{~m}$ in the central part of every lake. Phytoplankton samples for species composition analyses were collected with a plankton net; $25 \mu \mathrm{m}$ mesh size. Vertical and horizontal hauls were made. The samples were then preserved in $4 \%$ formaldehyde. For quantitative analyses, no concentrated water samples were collected and immediately fixed with $1 \%$ acidified Lugol's iodine ( $\mathrm{J}$ in $\mathrm{KJ}$ ). The abundance of algae was determined with the method of Utermöhl (1958) using an inverted microscope (MOD-2 PZO). The counting unit was the individual cell, filament or colony. The abundance is presented as the number of individuals per mililiter $\left(\mathrm{N}\right.$, ind. $\left.\mathrm{mL}^{-1}\right)$. Zooplankton samples were collected with a 1 litre Patalas bucket. Water was filtered through a plankton net; mesh size $25 \mu \mathrm{m}$. In order to obtain one sample of zooplankton, 10 litres of water were filtered. All zooplankton samples were preserved in Lugol's solution (Nogrady et al., 1993; Harris et al., 2000). The identification of phyto- and zooplankton was performed with the use of a light microscope Nikon Alphaphot-2 as well as a Panasonic camera and MultiScan computer software for image analysis.

The taxonomical identification of algae was made according to Ettl, 1978, 1983; Hindák, 2008; Javornickỳ, 2003; Komárek and Anagnostidis, 2007, 2008; Komárek and Fott, 1983; Komárek and Komárkowa, 2006; Komárek and Zapomèlova, 2007, 2008; Krammer and Lange-Bertalot, 1986, 1988, 1991a, 1991b; Popovskỳ and Pfiester, 1990; Růžička, 1977; Starmach, 1968, 1974, 1983; Wołowski, 1998; and Wołowski and Hindák, 2005. For the identification of zooplankton the commonly available studies and keys were used (Einsle, 1996; Flössner,
1972; Kiefer, 1978; Nogrady et al., 1993; Radwan, 2004; Rybak and Błędzki, 2010; Smirnov, 1996).

The collection of samples was measured along with the physical and chemical parameters of water, such as: Secchi disk visibility $(\mathrm{SD}, \mathrm{m})$, temperature $\left(\mathrm{WT},{ }^{\circ} \mathrm{C}\right)$, oxygen concentration (DO, $\mathrm{mg} \mathrm{L}^{-1}$ ), saturation (DO sat., \%), conductivity $\left(\mathrm{EC}, \mu \mathrm{S} \mathrm{cm}^{-1}\right)$, and $\mathrm{pH}$. Measurements of physico-chemical parameters were performer by Multi 3430SET F WTW field probes. Every two weeks, the content of chlorophyll $a\left(\mathrm{Chl}-a, \mu \mathrm{g} \mathrm{L}^{-1}\right)$ was determined with the method of Nusch (1980). Data on the water level (WL, $\mathrm{cm})$ and flow rate $\left(\mathrm{Q}, \mathrm{m}^{3} \mathrm{~s}^{-1}\right)$ of the Vistula River in Torun were obtained from the Meteorological and Hydrological Institute - the Regional Hydrological and Meteorological Station in Torun, Poland.

Pearson's simple correlation (IBM, 2012) was applied to analyse the relationships between the total number of plankton and the environmental factors. A canonical correspondence analysis (CCA) was performed using MVSP 3.22 software to show the relations between plankton and physico-chemical parameters at investigated sites (Kovach, 2010).

\section{RESULTS}

\section{Physical and chemical parameters}

The average water level in the Vistula River at the time the samples were collected was $252 \mathrm{~cm}$. The water level in the Vistula River remained at a rather average and low level (Fig. 2a). The highest WL in the Vistula River occurred in April $(353 \mathrm{~cm})$ and was almost $300 \mathrm{~cm}$ lower than the alarm status for Torun $(650 \mathrm{~cm})$. When the Vistula WL dropped below $230 \mathrm{~cm}$ both stations were isolated. This was the situation from late June to late July and in late summer during the whole month of August. In the remaining period, Site 1 was isolated but Site 2 was connected to the main channel of the Vistula. The flow rate (Fig. 2a) of water in the Vistula River in Torun during the study period, was lower than average and amounted to $750 \mathrm{~m}^{3} \mathrm{~s}^{-1}$. The maximum Q $\left(1208 \mathrm{~m}^{3} \mathrm{~s}^{-1}\right)$ was recorded in late April. The water level was strongly correlated with the flow rate in the Vistula River $(\mathrm{r}=0.92, \mathrm{P}<0.05)$.

The average water temperature (Fig. 2b) during the six months, at Site 1 , was $17.3^{\circ} \mathrm{C}$ and was lower by half a Celsius degree compared to the average temperature recorded at Site $2\left(17.8^{\circ} \mathrm{C}\right)$. The highest temperature $\left(22.9^{\circ} \mathrm{C}\right.$ on June $10,2008)$ and the lowest temperature $\left(9.0^{\circ} \mathrm{C}\right.$ on Apr 12 , 2008) were recorded at Site 2 . The average oxygen concentration in the waters of the Vistula oxbow lakes at Site 1 was $6.2 \mathrm{mg} \mathrm{L}^{-1}$, (saturation, $62 \%$ ), at Site 2 was $8.6 \mathrm{mg}$ $\mathrm{L}^{-1}$ (saturation, 93\%). The maximum value of this parameter, i.e. $14.6 \mathrm{mg} \mathrm{L}^{-1}(166 \%$ water saturation) was recorded at Site 2 (July 22). The minimum value, i.e. $1.6 \mathrm{mg} \mathrm{L}^{-1}$ (18\% water saturation) was recorded at Site 1 on Aug 05 
a)
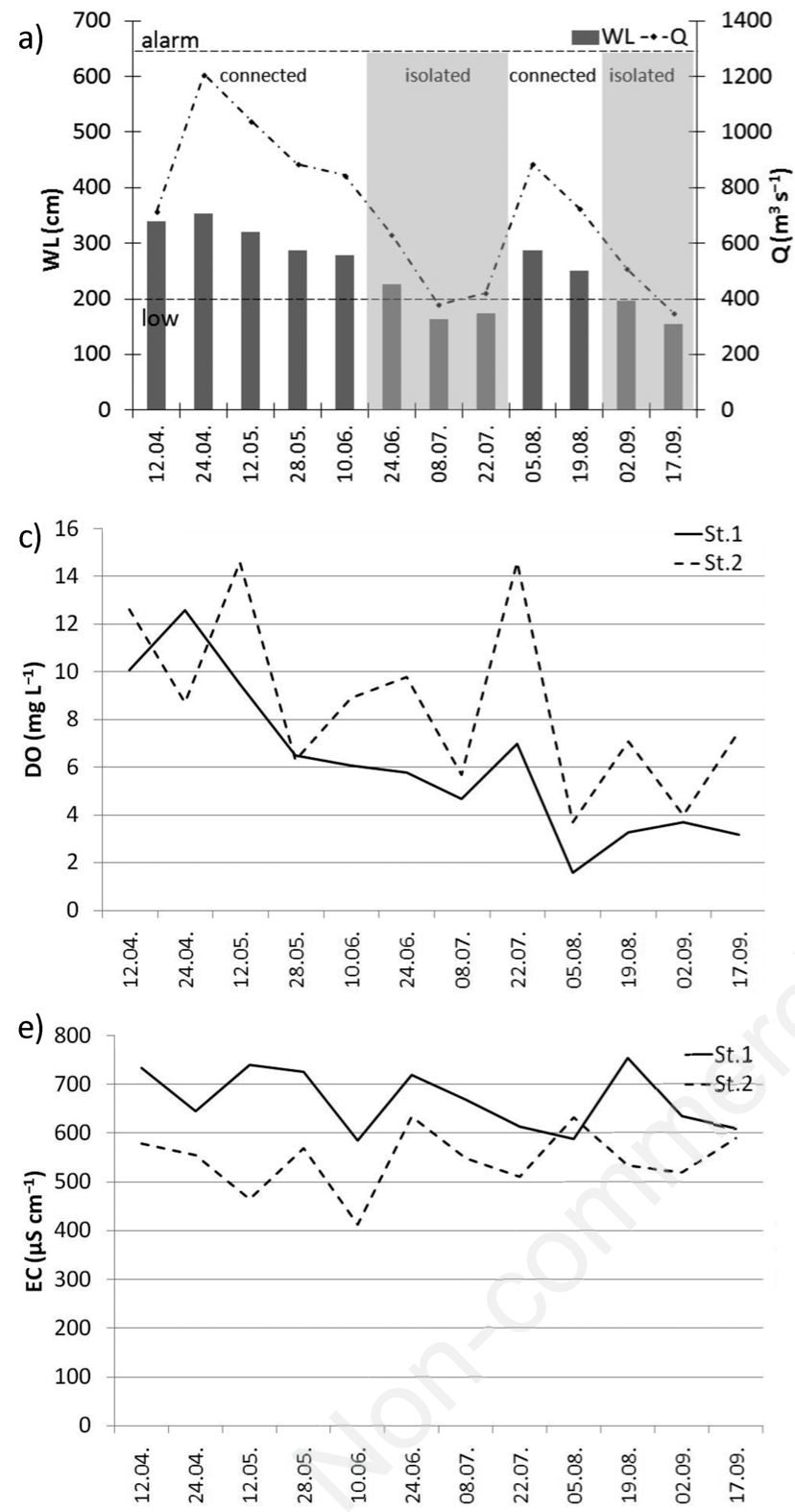

g)

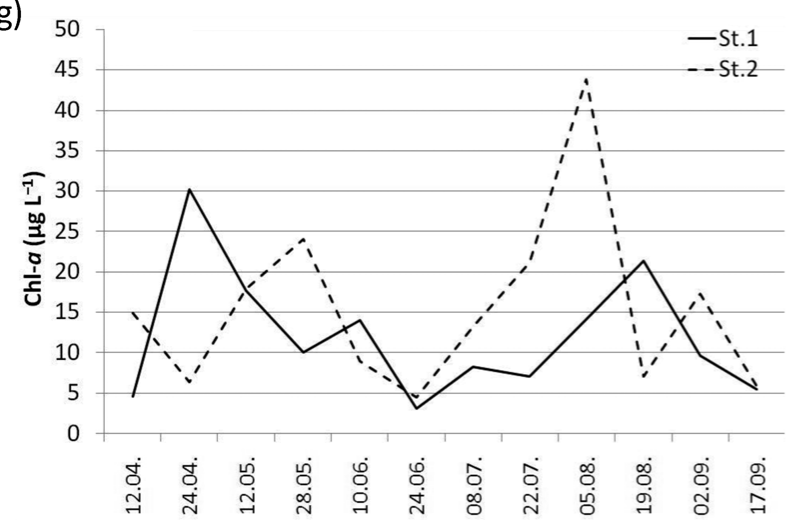

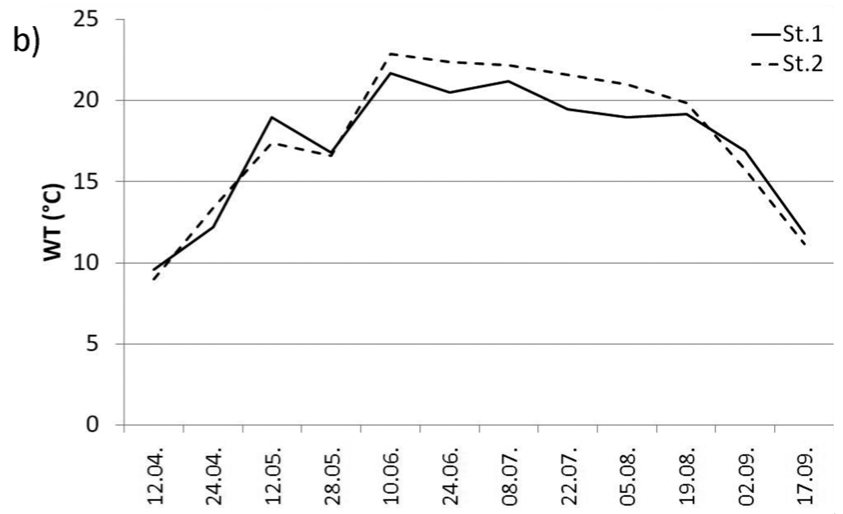

d)
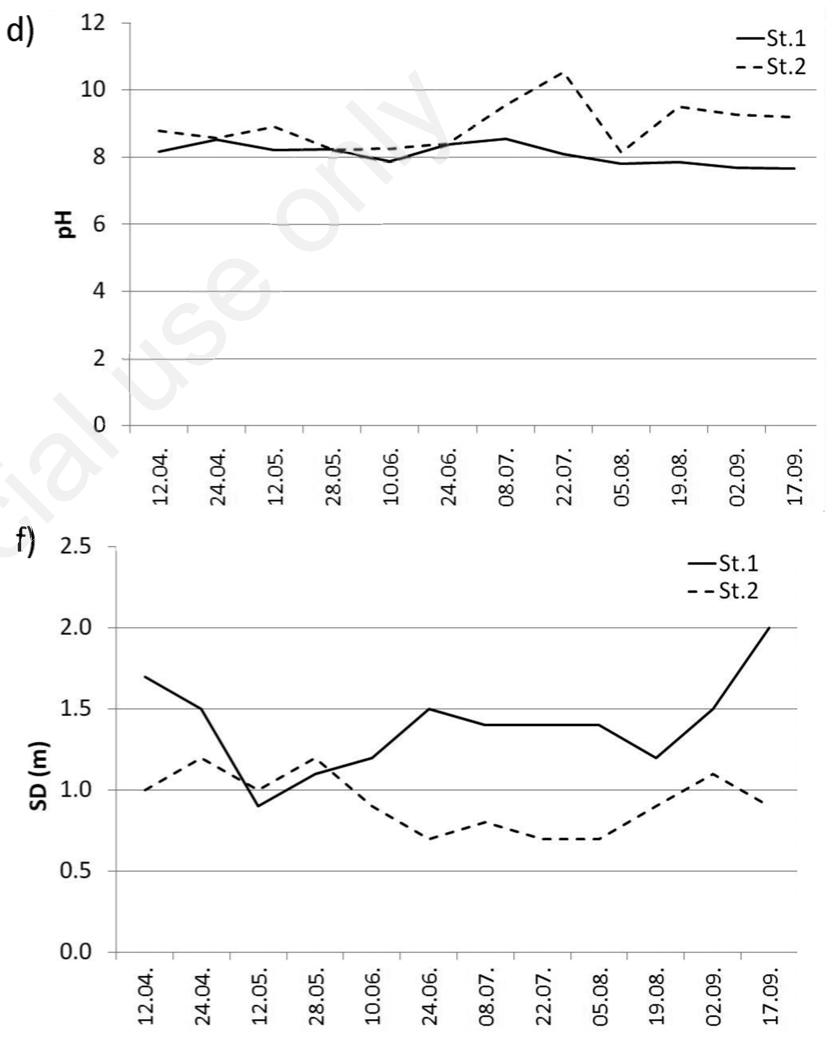

Fig. 2. Seasonal variation of the physic-chemical parameters: a) water level (WL, $\mathrm{m})$ and flow rate $\left(\mathrm{Q}, \mathrm{m}^{3} \mathrm{~s}^{-1}\right)$, the shadowed background indicates the period of disconnection between st.2 and river; b) water temperature (WT, $\left.{ }^{\circ} \mathrm{C}\right)$; c) oxygen concentration (DO, $\left.\mathrm{mg} \mathrm{L}^{-1}\right)$; d) $\mathrm{pH}$; e) electrolytic conductivity (EC, $\left.\mu \mathrm{S} \mathrm{cm}^{-1}\right)$; f) Secchi disk visibility (SD, m); g) content of chlorophyll $a\left(\mathrm{Chl}_{-} a, \mu \mathrm{g} \mathrm{L}^{-1}\right)$. 
(Fig. 2c). Water reaction (Fig. 2d) in the oxbow lakes was alkaline (basic). The average $\mathrm{pH}$ value at Site 1 amounted to 8.0 , whereas at Site 2 to 8.9 . The highest value of this parameter, i.e. 10.53 , was recorded at Site 2 , whereas the lowest value of 7.65 was recorded at Site 1 . The average value of EC (Fig. 2e) for Site 1 was $669 \mu \mathrm{S} \mathrm{cm}^{-1}$, for Site 2 was $546 \mu \mathrm{S} \mathrm{cm}^{-1}$. The maximum value of conductivity, i.e. $754 \mu \mathrm{S} \mathrm{cm}^{-1}$ was recorded at Site 1 (Sept 19), and the lowest value of $413 \mu \mathrm{S} \mathrm{cm}^{-1}$ was recorded at Site 2 (June 10). The mean Secchi depth (Fig. 2f) at Site 1 amounted to $1.4 \mathrm{~m}$ and ranged from 0.9 (May 11) to 1.7 (Apr 12). Whereas the average SD value at Site 2 came to $0.9 \mathrm{~m}$ and ranged from $0.7 \mathrm{~m}$ (June 24, July 22, Sept 05) to $1.2 \mathrm{~m}$ (Apr $24)$. The water transparency was significantly negatively correlated to the temperature at both sites $(\mathrm{r}=-0.61$; $\mathrm{r}=-0.62$ ). The average value of chlorophyll $a$ (Fig. $2 \mathrm{~g}$ ) for Site 1 was $12.14 \mu \mathrm{g} \mathrm{L}^{-1}$, for Site $2-15,42 \mu \mathrm{g} \mathrm{L}^{-1}$. The maximum value of chlorophyll $a 43.8 \mu \mathrm{g} \mathrm{L}{ }^{-1}$ was recorded at Site 2 (Aug 5), and the lowest value of $3.1 \mu \mathrm{g} \mathrm{L}^{-1}$ was recorded at Site 1 (June 24). Tab. 1 summarizes the mean values and ranges of physico-chemical parameters in the two investigated sites.

\section{Plankton}

At Site 1, there were 109 taxa of phytoplankton recorded (Supplementary Tab. 1). The richest species groups were: diatoms, 39 taxa (36\% of species composition); green algae 30 taxa (28\%), Euglenophyta 12 taxa (11\%), and Chrysophyceae 10 taxa (9\%). Other algae phyla were represented by only a few species. At Site 1, sixty-nine forms and species of zooplankton were recorded: 54 taxa (78\% of species composition) of Rotifera, 11 species (16\%) of Cladocera, and 4 species $(6 \%)$ of Copepoda.

At Site 2, 188 taxa of phytoplankton were recorded (Supplementary Tab. 1). The richest species groups were: diatoms, 100 ( $53 \%$ of species composition); green algae 59 taxa (31\%), Euglenophyta 12 taxa (6\%), and Cyanoprokaryota 10 taxa $(5 \%)$. Other algae phyla were represented by only a few species. There were 58 forms and species of zooplankton: 49 taxa ( $85 \%$ of the species composition) of Rotifera, 7 species (12\%) of Cladocera, and 2 species (3\%) of Copepoda. At the studied sites, larval forms of copepodites and nauplii were recorded. All together, 41 species of zooplankton were recorded at both sites, 25 species were recorded only at Site 1, and 17 species were recorded only at Site 2 (Supplementary Tab. 2).

The average count of total phytoplankton (Fig. 3a) was over two times lower at Site $1\left(1653\right.$ ind. $\left.\mathrm{mL}^{-1}\right)$ compared to Site 2 (4168 ind. $\mathrm{mL}^{-1}$ ). The mean abundance of total zooplankton (Fig. 3b) was nearly two times higher at Site 1 (3934 ind. $\mathrm{L}^{-1}$ ) compared to Site 2 (1657 ind. $\left.\mathrm{L}^{-1}\right)$. Cryptophyta dominated in phytoplankton at Site 1, constituting $60 \%$ of the total count (1081 ind. $\mathrm{mL}^{-1}$ ), Chlorophyta made up 16\% (292 ind. $\mathrm{mL}^{-1}$ ), and Chrysophyceae 13\% (240 ind. $\left.\mathrm{mL}^{-1}\right)$. Rotifera dominated among zooplankton at Site 1 (Supplementary Tab. 2), constituting $81 \%$ of the total count (3178 ind. $\mathrm{L}^{-1}$ ). Cladocera made up 3\% (117 ind. $\left.\mathrm{L}^{-1}\right)$, and Copepoda 16\% (639 ind. $\left.\mathrm{L}^{-1}\right)$.

Bacillariophyceae dominated in phytoplankton at Site 2 , constituting $43 \%$ of the total count (1813 ind. $\left.\mathrm{mL}^{-1}\right)$. Cryptophyta made up 27\% (1132 ind. $\mathrm{mL}^{-1}$ ), and Chlorophyta $24 \%$ (1014 ind. $\left.\mathrm{mL}^{-1}\right)$. Rotifers also predominated at Site 2 , constituting $78 \%$ of the total number (1294 ind. $\mathrm{L}^{-1}$ ). Copepoda were dominant among crustaceans. The average count of copepods was 248 ind. $\mathrm{L}^{-1}$, which made up $15 \%$ of the zooplankton abundance. Cladocera accounted for $7 \%$, with the average count of 115 ind. $\mathrm{L}^{-1}$. The dominant species among Rotifera were: Keratella cochlearis (Gosse, 1851), Keratella quadrata (Müller, 1786), and Asplanchna priodonta (Gosse, 1850), among Cladocera: Bosmina longirostris (Müller, 1785), while among Copepoda, larval forms of copepods: nauplii and copepodites dominated.

In the floodplain lake isolated from the Vistula River,

Tab. 1. Range and mean values of physicochemical parameters over the growing season (from April to September 2008) in two floodplain lakes.

\begin{tabular}{|c|c|c|c|c|c|c|}
\hline \multirow[t]{2}{*}{ Parameters } & \multicolumn{3}{|c|}{ Site 1} & \multicolumn{3}{|c|}{ Site 2} \\
\hline & Mean & Range & Standard deviation & Mean & Range & Standard deviation \\
\hline $\mathrm{SD}(\mathrm{m})$ & 1.4 & $0.9-2.0$ & 0.29 & 0.9 & $0.7-1.2$ & 0.18 \\
\hline $\mathrm{DO}\left(\mathrm{mg} \mathrm{L}^{-1}\right)$ & 6.2 & $1.6-12.6$ & 3.23 & 8.6 & $3.7-14.6$ & 3.72 \\
\hline DO sat. $(\%)$ & 62 & $18-113$ & 28.81 & 93 & $1.3-166$ & 41.06 \\
\hline WT $\left({ }^{\circ} \mathrm{C}\right)$ & 17.3 & $9.6-21.7$ & 3.99 & 17.8 & $9.0-22.9$ & 4.69 \\
\hline $\mathrm{pH}$ & 8.0 & $7.7-8.5$ & 0.31 & 8.9 & $8.1-10.5$ & 0.7 \\
\hline $\mathrm{EC}\left(\mu \mathrm{S} \mathrm{cm} \mathrm{cm}^{-1}\right)$ & 669 & $586-754$ & 66.11 & 546 & $413-635$ & 67.41 \\
\hline Chl- $a\left(\mu \mathrm{g} \mathrm{L}^{-1}\right)$ & 12.14 & $3.12-30.18$ & 7.87 & 15.42 & $4.48-43.78$ & 11.0 \\
\hline TSI (SD, Chl- $a$ ) & 54.3 & $48.0-60.2$ & 4.23 & 58.4 & $53.1-66.4$ & 3.69 \\
\hline
\end{tabular}

SD, Secchi disk visibility; DO, dissolved oxygen; WT, water temperature; EC, electrolytic conductivity; TSI, trophic state indices. 
temperature changes adversely affected the abundance of diatoms and chrysophyceae $(\mathrm{r}=-0.50, \mathrm{r}=-0.52, \mathrm{P}<0.05)$, but changes positively correlated (Tab. 2) with the abundance of crustacean zooplankton $(r=0.72, \mathrm{P}<0.05)$. The inverse correlation between the abundance of green algae $(\mathrm{r}=-0.63, \mathrm{P}<0.05)$, and water transparency $(\mathrm{SD})$ was also observed at Site 1. Water level (WL) and flow rate (Q) were positively correlated with the number of diatoms, Chrysphyceae, and green algae (Tab. 2) at isolated site.

The temperature was negatively correlated with the abundance of total phytoplankton (especially Cryptophyta, $\mathrm{r}=-0.60$ and diatoms $\mathrm{r}=-0.63, \mathrm{P}<0.05)$ and zooplankton at that floodplain lake which was periodically connected with the Vistula River (Tab. 2). The rotifer abundance was positively correlated with the level of water in the river and water oxygen saturation at Site 2. The water level was closely and positively associated with the total abundance of zooplankton $(\mathrm{r}=0.76, \mathrm{P}<0.05)$ and phytoplankton $(\mathrm{r}=0.76, \mathrm{P}<0.05)$; Cryptophyta, Bacillariophyceae, and Chlorophyta. The crustacean zooplankton (abundance) development was positively correlated with temperature $(\mathrm{T})$ and negatively with transparency $(\mathrm{r}=-0.52, \mathrm{P}<0.05)$. High water temperatures were associated with high abundance of dinoflagellates $(\mathrm{r}=0.58$,
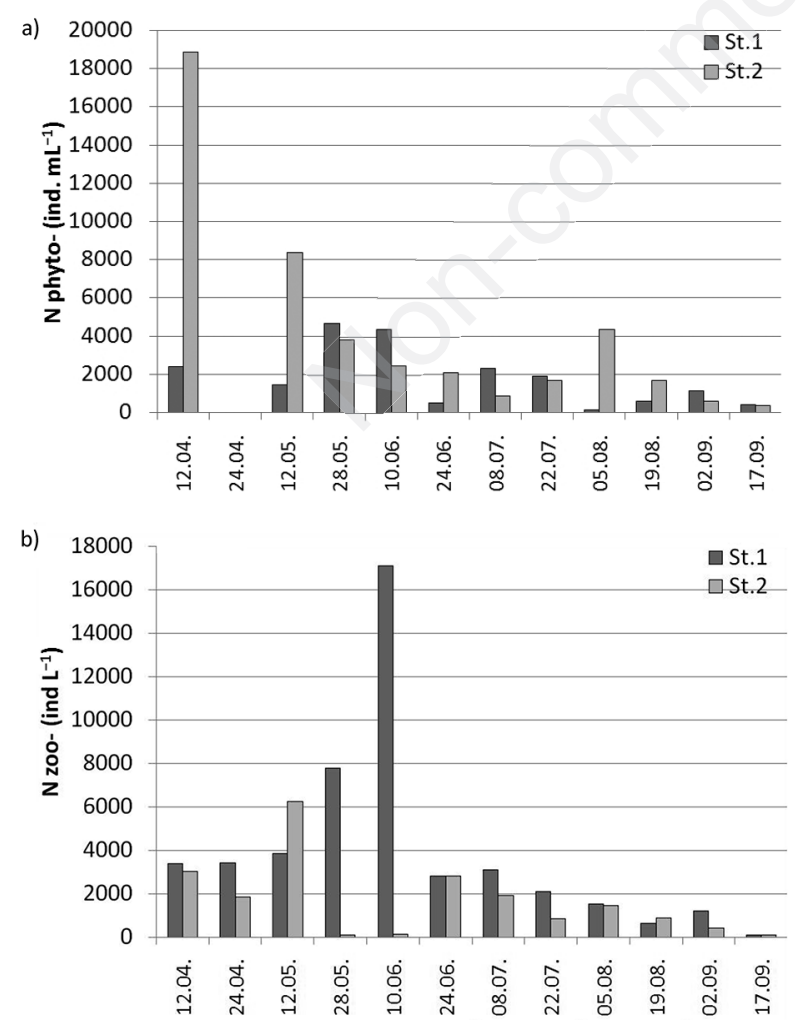

Fig. 3. Temporal variation on the total abundance of phyto- (a) and zooplankton (b).
$\mathrm{P}<0.05)$ and copepods $(\mathrm{r}=0.55, \mathrm{P}<0.05)$. Copepods also negatively responded to an increase in the water level of the river and connected floodplain lake (Tab. 2).

The results of the CCA analysis, at Site 1 (Fig.4a), completely reflected the simple Pearson correlation between plankton and physico-chemical factors. The development of crustacean zooplankton had a strong positive correlation with the temperature and inversely with the water level and flow rate in the Vistula River. Phytoplankton growth reduced water transparency. The concentration of chlorophyll a was dependent on the abundance of large algae i.e. Dinophyta, Chlorophyta, Cyanoprokaryota and Euglenophyta. While at Site 2 (Fig.4b), environmental factors were very disturbed by irregular infusions of river water into the oxbow lake. The changes were so dynamic that it was difficult to find a clear relationship between the plankton and physico-chemical factors. The results of the CCA analysis confirmed only simple correlations between crustacean plankton, Dinophyta, and the water level and temperature.

\section{DISCUSSION}

After the regulation of the lower Vistula, the exchange of water between the river and many lakes is limited and is observed only during floods when water level in the Vistula is extremely high (Napiórkowski and Napiórkowska, 2014).

Our research indicates that the irregular inflows of water from the river destabilize environmental conditions in the investigated oxbow lakes. Water from the river reduced transparency, decreased the temperature, and inhibited macrophyte growth in the lakes. Replenished macrophytes were not able to provide refuge for zooplankton (i.e. did not offer protection against predators). Following the destruction of macrophyte community, planktonic algae became the main primary producers.

The investigated oxbow lakes had slightly different trophic state indices (TSI). With TSI=54, Site 1 (Carlson, 1977) can be classified as eutrophic. This lake is shallow, with clear, highly transparent water (the bottom can be seen) and has abundant submerged vegetation (Scheffer, 1998). The lake's stable conditions resulted from the fact that for several years the lake's water has not mixed with the river's water (limnophase). The second oxbow lake (Site 2), located just behind the flood embankments is connected with the river through a channel, and thus has continuous exchange of water with the river. The lake is regularly flooded (potamophase). Only extremely low level of water in the Vistula (below $230 \mathrm{~cm}$ ) limit the water exchange. The lake has a slightly higher trophic level with an average TSI of 58 .

Frequent water exchange caused resuspension of bottom sediment and reduced water transparency in the lake. This water body resembles a shallow lake in a turbid state. 
Despite many negative consequences of the inflow of river's water, it also leads to the refreshing of water in the lake. The Vistula is characterized by a stable oxygen regime (Glińska-Lewczuk and Burandt, 2011). When its lakes suffer from oxygen depletion, the river's water improves their saturation. This could be observed in the studied oxbow lakes in August and September, 2008. During these months, at Site 1 (the lake isolated from the Vistula River), significant oxygen deficit was observed. At Site 2 (the lake connected to the river), though, oxygen depletion was not noted. Good oxygen conditions at Site 2 could, among other factors, could have promoted the development of zooplankton, the fact seems to be confirmed by the correlation between the oxygen content and the average zooplankton abundance. At Site 1 a relationship of this kind was not observed.

Temperature is one of the most important physical factors determining biological processes in aquatic environments (de Azevedo and Bonecker, 2003; Gyllström et al., 2008; Starmach et al., 1976; Vadadi-Fülöp et.al., 2009). The average water temperature in the oxbow lake isolated from the Vistula River was lower than in the lake connected with the river. During the summer the temperature at Site 2 was higher. When connection was observed, temperature was lower because a cooling effect of the river. Increased temperature had an ambiguous effect on phytoplankton growth: it could have inhibited the growth of diatoms and Chrysophyceae at Site 1, and diatoms and Cryptophyta at Site 2. A positive effect of the temperature on the development of dinoflagellates was quite remarkable, though only at Site 2 . Raised temperature also increased the abundance of crustaceans at both stations (Tab. 2). Site 1 was a shallow landlocked oxbow lake, which heats up easily. As high temperature is favourable for the development of Cladocera (Forro et al., 2008), more Cladocera species were recorded at this site.

The phytoplankton species composition in oxbow lakes is usually similar to the one typical of eutrophic lakes, with several extra species found only in these specific ecosystems (Krasznai et al., 2010). Wojciechowska et al. (2007) reported that the number of species of planktonic algae in oxbow lakes ranges from 250 to 300 . The number of species found in an ecosystem is often related to the number of analysed samples; in the oxbow lakes of the Tisza River (Krasznai et al., 2010), 50 taxa of phytoplankton were recorded in 4 samples and 308 taxa in 19

Tab. 2. The relationship between planktonic organisms abundance and environmental variables.

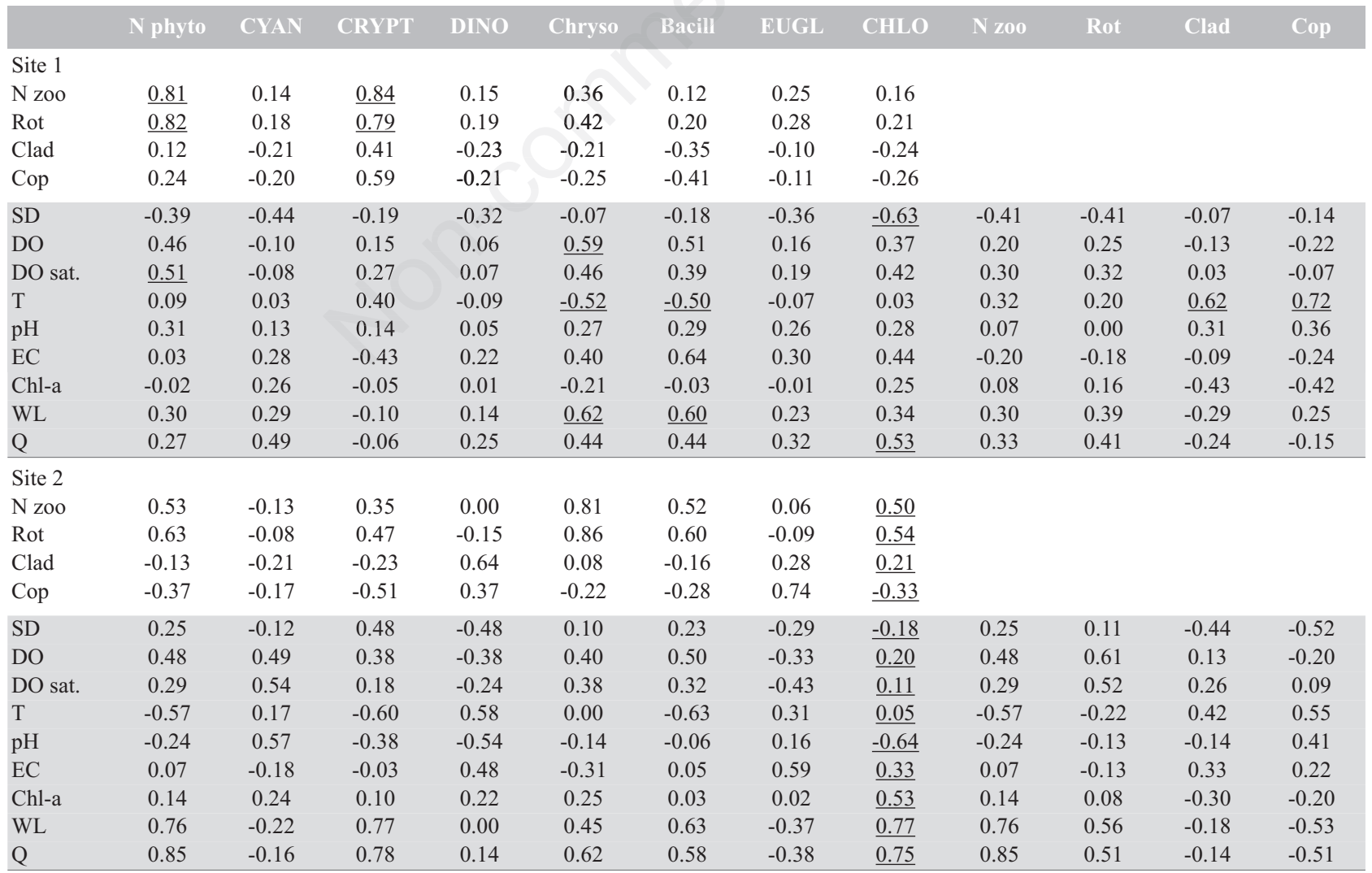

CYAN, Canoprokaryota; CRYPT, Cryptophyta; DINO, Dinophyta; Chryso, Chrysophyceae; Bacill, Bacillariophyceae; EUGL, Euglenophyta; CHLO, Chlorophyta; Rot, Rotifera; Clad, Cladocera; Cop, Copepoda; Pearson correlation coefficient P<0.05; statistical significances are underlined. 
samples. The number of phytoplankton species identified in the Vistula River's oxbow lakes seems low but is in fact similar to the number of taxa identified in the Amazon floodplain lakes (Melo and Huszar, 2000).

Kuczyńska-Kippen and Nagengast (2006), who studied shallow lakes dominated by macrophytes, proved that these water bodies constitute a better habitat for zooplankton than oxbow lakes with sparse macrophytes. A welldeveloped macrophyte community in oxbow lakes ensures the diversity of zooplankton. The lake which was cut off from the Vistula River (Site 1) had a more abundant zooplankton community. The bottom of this lake was

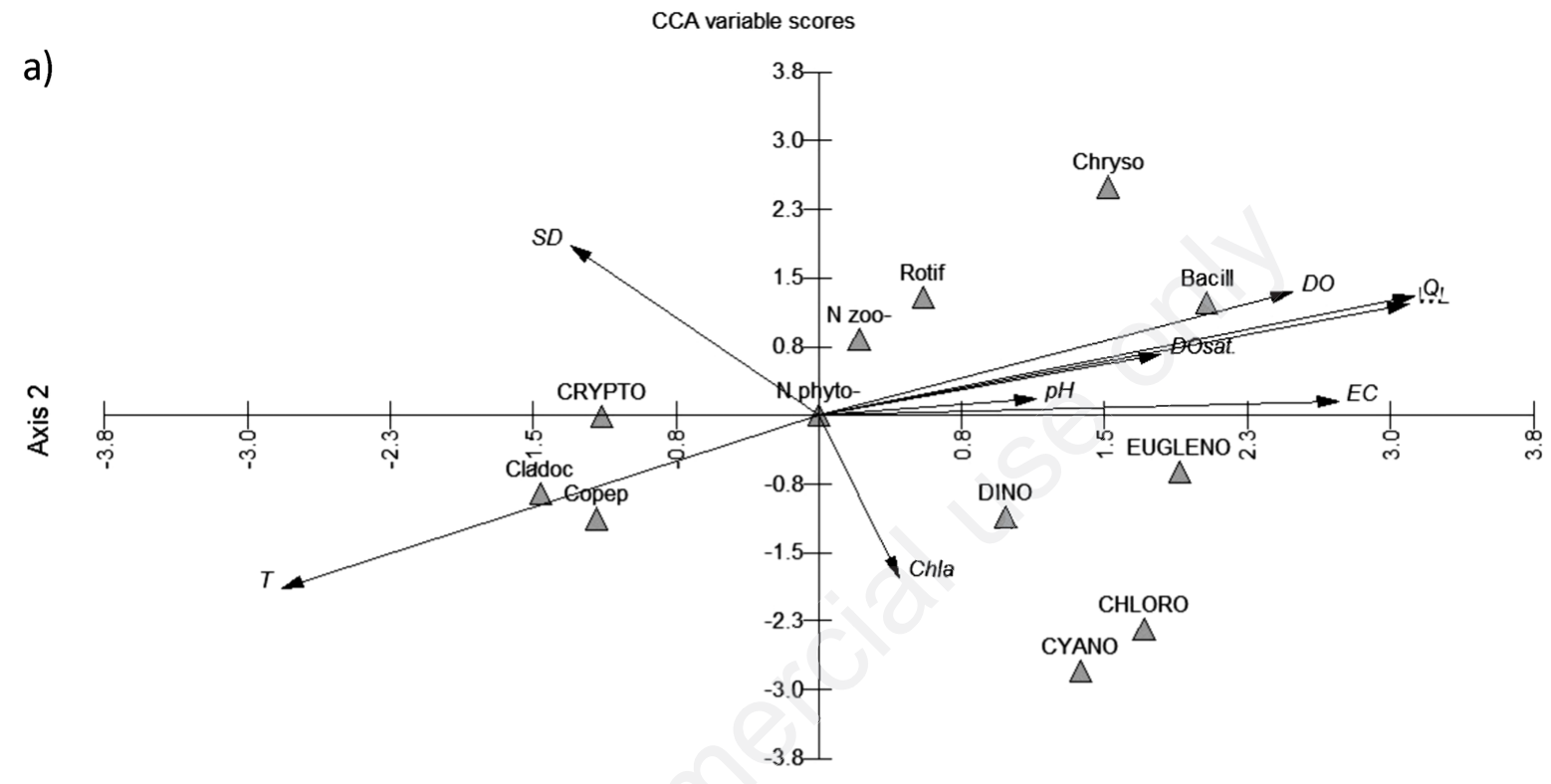

Vector scalina: 10.30

Axis 1

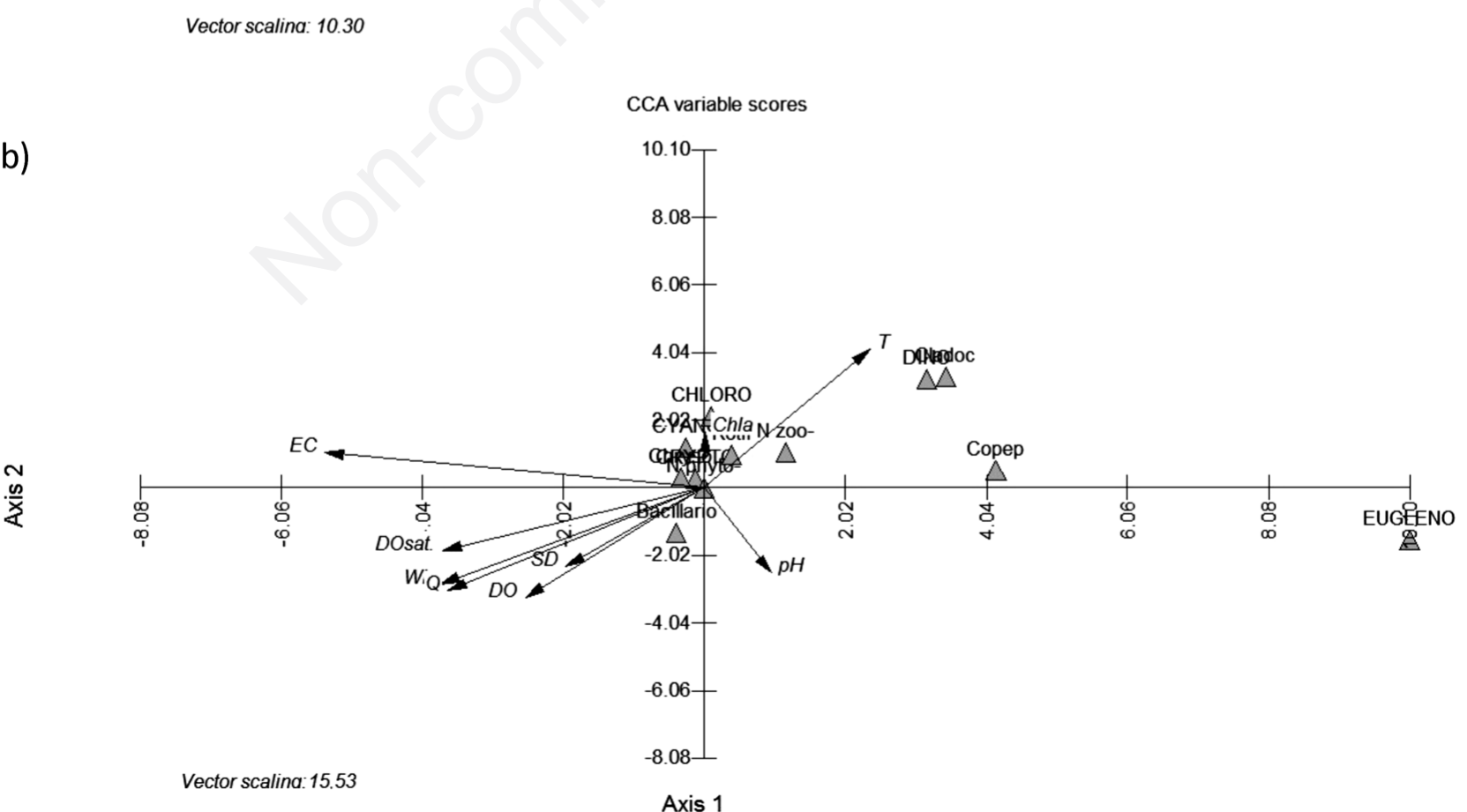

Fig. 4. Canonical correspondence analysis (CCA) biplot of plankton and physico-chemical parameters: a) at Site 1 (Axis 1 , $48.2 \%$ of explanation; Axis 2, 22.3\% of explanation); b) at Site 2 (Axis 1, 41.3\% of explanation; Axis 2, 21.3\% of explanation). 
thickly covered with elodeids (Ceratophyllum, Myriophyllum). Sixty-six species of zooplankton were identified, 25 of which were only found only at this site. Rotifer species were predominant at both sites $(79 \%$ at Site 1 and $85 \%$ at Site 2). According to many authors (Keckeis et al., 2003; Pithart et al., 2007; Schöll, 2009), rotifers are the dominant group in heleoplankton. Because of their high tolerance to adverse conditions (Radwan, 2004), they are commonly found in both stagnant and flowing waters.

Phytoplankton abundance at the two sites was different. In the lake isolated from the river it was two and a half times lower than in the lake connected with the river. Small nanoplankton forms, typical of unstable, mixed ecosystems (Wojciechowska et al., 2007), dominated in both lakes. Common in oxbow lakes, Cryptophyta were also predominant in the investigated isolated lake. According to the classification by Reynolds et al. (2002) updated by Padisák et al. (2009), Cryptophyta represent the $\mathrm{Y}$ functional group adapted to poor light conditions. As mixotrophs, they are present in oxbow lakes with abundant organic matter, which comes mainly from macrophyte decomposition (Jones, 2000). These forms are active, and can migrate into the depths of lakes under sufficiently stable conditions. This ability allows them to compete with other algae, e.g. cyanobacteria. Moreover, Cryptophyta serve as food for zooplankton (Reynolds et al., 2002). It seems that the relatively low abundance of these algae at Site 1 and the high correlation between the Cryptophyta abundance and the total zooplankton abundance and between the Cryptophyta abundance and the rotifer abundance resulted from zooplankton pressure (Tab.2).

Site 2 was under the substantial influence of the Vistula River. The water inflow was responsible for a greater total abundance of phytoplankton (Tab. 2). Small-sized diatoms, dominant in phytoplankton, were supplied with the river's water and belonged to the $\mathrm{C}, \mathrm{D}$, and $\mathrm{P}$ associations (Reynolds et al., 2002; Padisák et al., 2003). Mihaljević et al. (2009) recorded a significant contribution of diatoms to phytoplankton abundance in oxbow lakes during potamophase, as was the case in the studied oxbow lake (Site 2). Diatoms abundance was correlated with water level and flow rate in the Vistula (Tab. 2). Small organisms were also dominant in the zooplankton community. The most abundant rotifers constituted from $78 \%$ to $81 \%$ of the total zooplankton.

Demetraki-Palaeolog (2007) maintains that rotifers generally represent about $90 \%$ of total zooplankton abundance in rivers, Baranyi et al. (2002) reported that rotifers accounted for almost $85 \%$, and Illyová et al. (2008) reported 67 to $78 \%$ zooplankton abundance in the backwater of the Danube River. It has been suggested that the apparent predominance of rotifers in rivers and floodplain lakes may be connected with their small size and relatively short generation time compared to the larger crus- taceans (van Dijk and van Zanten, 1995; Lair, 2006; Radwan, 2004). In addition, rotifers appear to be better adapted to adverse conditions of lotic and semi-lotic habitats (Marneffe et al., 1996).

The following species prevailed in the rotifers' community in the investigated oxbow lakes: Keratella cochlearis, Keratella quadrata, and Asplanchna priodonta. Among the Cladocera, the most frequently found was Bosmina longirostris. Baranyi et al. (2002) studying the oxbow lakes of the Danube River, also noted that Bosmina longirostris dominated among cladocerans. Similar results were also obtained by Vadadi-Fülöp et al. (2009). No dominant species among copepods were identified due to the small number of mature individuals. Copepod larval forms (nauplii and copepodites) were the most frequent, similarly to other oxbow lakes (Spaink et al., 1998; Hein et al., 1999; Keckeis et al., 2003; Schöll, 2009). Copepods dominated over cladocerans among the crustaceans in the oxbow lakes of the lower Vistula. Cladocerans prefer stable conditions because they are more sensitive to periodic inflows of river's water (Vadadi-Fülöp, 2009). For this reason, the number of cladoceran species was greater at Site 1 (12 species) than at Site 2 ( 7 species) since Site 2 is periodically connected with the river.

The average zooplankton abundance at Site 1 was more than twice as high as that at Site 2. This indicates that this lake constitutes a better habitat for zooplankton due to its ecological stability (conditions similar to those found in ponds), higher temperature in summer (de Azevedo and Bonecker, 2003), and nutrient availability (high abundance of small phytoplankton). The macrophyte abundance in the studied oxbow lakes was also important. Site 1, with its stability (no inflow of water from the river), offered better conditions for the development of macrophytes than Site 2 which was periodically flooded by the water from the Vistula River. It seems obvious that better developed macrophyte community provides better cover and substrate for zooplankton. In addition, both submerged and emerged plants improve oxygen saturation (KuczyńskaKippen and Nagengast, 2006).

The phytoplankton abundance at Site 1 was several times lower than at Site 2. This difference may have been caused by zooplankton grazing. In oxbow lakes connected with rivers the impact of zooplankton grazing is less significant (Keckeis et al., 2003), which explains why zooplankton pressure of on phytoplankton was much higher at Site 1.

\section{CONCLUSIONS}

The comparison of two oxbow lakes, i.e. the lake isolated from the main stem of the river and the lake periodically connected with the river, shows that the lakes have different environmental conditions, different plankton abundances and species compositions. Due to its lower 
trophic status, the isolated lake had lower temperature, $\mathrm{pH}$, chlorophyll $a$ concentration and dissolved oxygen content. In this water body phytoplankton was less abundant and contained a smaller number of species, but zooplankton was better developed. These conditions ensured species richness and Cladocera abundance. The contribution of Cryptophyta and Rotifera was high in both lakes. Diatoms were more frequent in the lake periodically flooded by the river. On the other hand, the conditions for zooplankton development were worse in the absence of macrophytes and nutrients.

The results of the research indicate that species composition, plankton abundance, and Chl- $a$ concentration depended primarily on whether there was an exchange of water between the river and the lake. Hydrological conditions affected the relationships between biota components.

\section{REFERENCES}

Anderson SMA, Bonecker CC, 2004. Rotifers in different environments of the Upper Parana river floodplain (Brazil): richness, abundance and the relationship with connectivity. Hydrobiologia 522:281-290.

Baranyi Ch, Hein T, Holarek C, Keckeis S, Schiemer F, 2002. Zooplankton biomass and community structure in a Danube River floodplain system: effects of hydrology. Freshwater Biol. 47:473-482.

Basu BK, Kalff J, Pinel-Alloul B, 2000. The influence of macrophyte beds on plankton communities and their export from fluvial lakes in the St Lawrence River. Freshwater Biol. 45:373-382.

Carlson RE, 1977. A Trophic State Index for Lakes. Limnol. Oceanogr. 22:361-369.

de Azevedo F, Bonecker CC, 2003. Community size structure of zooplanktonic assemblages in three lakes on the upper River Paraná floodplain, PR-MS, Brazil. Hydrobiologia 505:147-158.

Dembowska E, Głogowska B, Dąbrowski K, 2012. Dynamics of algae communities in the oxbow lake (Vistula River, Poland). Arch. Pol. Fish. 20:27-37.

Dembowska E, Napiórkowski P, 2012. [Why do we have to protect old river beds?]. [Article in Polish with English Abstract]. Kosmos, Problemy Nauk Biologicznych 61:341-349.

Demetraki-Paleolog A, 2007. [Plankton Rotifers (Rotifera) in rivers of the Western Lublin Region]. [Thesis in Polish]. $\mathrm{PhD}$ Thesis, Agricultural University in Lublin.

Einsle, U, 1996. Copepoda: Cyclopoida - genera Cyclops, Megacyclops, Acanthocyclops, p. 1-82. In: H.J. Dumont (ed.), Guides to the identification of the microinvertebrates of the continental waters of the world 10. SPB Acad. Publ.

Ettl H, 1978. [Xanthophyceae, p. 1-530]. In: H. Ettl, J. Gerloff and H. Heynig (eds.), [Süßwasserflora von Mitteleuropa, Bd. 3].[Book in German]. Gustav Fischer Verlag.

Ettl H, 1983. [Chlorophyta I: Phytomonadina, p. 1-807]. In: H. Ettl, J. Gerloff, H. Heynig and D. Mollenhauer (eds.), [Süßwasserflora von Mitteleuropa Bd. 9].[Book in German]. Gustav Fischer Verlag.

Flössner, D, 1972. [Die tierwelt Deutschlands. 60 teil. Krebstiere, Crustacea. Kiemen und Blattfüsser, Branchiopoda
FischläuseBranchiura].[Book in German]. Gustav Fischer Verlag: $501 \mathrm{pp}$.

Forro L, Korovchinsky NM, Kotov AA, Petrusek A, 2008. Global diversity of cladocerans (Cladocera; Crustacea) in freshwater. Hydrobiologia 595:177-184.

Glińska-Lewczuk K, Burandt P, 2011. Effect of river straightening on the hydrochemical properties of floodplain lakes: Observations from the Łyna and Drwęca Rivers, N Poland. Ecol. Eng. 37:786-795.

Grabowska M, Glińska-Lewczuk K, Obolewski K, Burandt P, Kobus S, Dunalska J, Kujawa R, Goździejewska A, Skrzypczak A, 2014. Effects of hydrological and physicochemical factors on phytoplankton communities in floodplain lakes. Pol. J. Environ. Stud. 23:713-725.

Gross EM, 2003. Allelopathy of aquatic autotrophs. Crit. Rev. Plant Sci. 22:313-339.

Gross EM, Hilt S, Lombardo P, Mulderij G, 2007. Searching for allelopathy interaction-State of the art and open questions. Hydrobiologia 584:77-88.

Gumiri S, Ardianor L, Wulandari L, Buchar T, Iwakuma T, 2005. Seasonal dynamics of zooplankton communities in interconnected tropical swamp lake ecosystem. Vehr. Int. Verein. Theor. Angew. Limnol. 29:179-184.

Gyllström ML, Hansson A, Jeppesen E, García-Criado F, Gross E, Irvine K, Kairesalo T, Kornijow R, Miracle MR, Nykänen M, Nges T, Romo S, Stephen D, Van Donk E, Moss B, 2008. The role of climate in shaping zooplankton communities of shallow lakes. Limnol. Oceanogr. 50:2008-2021.

Harris RP, Wiebe PH, Lenz J, Skjoldal HR, Huntley M, 2000. Zooplankton methodology manual. Academic Press: 684 pp.

Hein T, Heiler G, Pennetzdorfer D, Riedler P, Schagerl M, Schimer F, 1999. The Danube restoration project: Functional aspects and planktonic productivity in the floodplain system. Regul. Rivers Res. Manage. 15:259-270.

Hein T, Baranyi Ch, Reckendorfer W, Schiemer F, 2004. The impact of surface water exchange on the nutrient and particle dynamics in side-arms along the River Danube, Austria. Sci. Tot. Environ. 328:207-218.

Hillbricht-Ilkowska A, 1999. Shallow lakes in lowland river systems: Role in transport and transformations of nutrients and in biological diversity. Hydrobiologia 408/409:349-358.

Hindák F, 2008. Colour atlas of Cyanophytes. Veda Publishing House of the Slovak Academy of Sciences: $253 \mathrm{pp}$.

IBM, 2012. IBM SPSS Statistic for Windows, ver. 21.0. IBM Corp., Armonk, NY, USA.

Illyová M, Bukvayová K, Némethová D, 2008. Zooplankton in a Danube River Arm near Rusovce (Slovakia). Biol. B 63:566-573.

Javornickỳ P, 2003. Taxonomic notes on some freshwater planktonic Cryptophyceae based on light microscopy. Hydrobiologia 502:271-283.

Jezierska-Madziar M, 2005. [Oxbow lakes as important part of River ecosytem].[Book in Polish]. Wydawnictwo Akademii Rolniczej Poznań: 88 pp.

Jones RJ, 2000. Mixotrophy in planktonic protists: an overview. Freshwater Biol. 45:219-226.

Junk WJ, Bayley PB, Sparks RE, 1989. The flood pulse concept in river-floodplain systems. In: D.P. Dodge (ed.) Proceedings Int. Large River Symp. Can. Spec. Publ. Fish. Aquat. Sci. 106:110-127. 
Kasten J. 2003. Inundation and isolation: dynamics of phytoplankton communities in seasonal inundated flood plain waters of the Lower Odra Valley National Park - Northeast Germany. Limnologica 33:99-111.

Keckeis S, Baranyi Ch, Hein T, Holarek C, Riedler P, Schiemer F, 2003. The significance of zooplankton grazing in a floodplain system of the River Danube. J. Plankton Res. 25:243253.

Kiefer F, 1978. [Freilebende Copepoda, p. 1-343]. In: F. Kiefer and G. Fryer (eds.) [Das zooplankton der Binnengewässer. 2.Teil].[Book in German]. E. Schweizerbart'sche Verlagsbuchhandlung.

Kentzer A, Dembowska E, Giziński A, Napiórkowski P, 2010. Influence of the Włocławek Oxbow lake on hydrochemistry and plankton of a large, lowland river (the Lower Vistula River, Poland). Ecol. Eng. 36:1747-1753.

Komárek J, Anagnostidis K, 2007. [Cyanoprokaryota 2. Teil: Oscillatoriales, p. 1-759]. In: B. Büdel, G. Gärtner, L. Krienitz and M. Schagerl (eds.), [Süßwasserflora von Mitteleuropa, Bd. 19/2]. [Book in German]. Spektrum Akademischer Verlag.

Komárek J, Anagnostidis K, 2008. [Cyanoprokaryota 1. Teil: Chroococcales, p. 1-548]. In: H. Ettl, J. Gerloff, H. Heynig and D .Mollenhauer (eds.), [Süßwasserflora von Mitteleuropa, Bd. 1/19].[Book in German]. Spektrum Akademischer Verlag.

Komárek J, Fott B, 1983. [Chlorophyceae (Grünalgen), O. Chlorococcales. Die Binnengewässer. Das Phytoplankton des Süßwassers, Systematik und Biologie, 7 Teil.1. Hälfte].[Book in German]. E. Schweizerbart'sche Verlagsbuchhandlung: $1044 \mathrm{pp}$.

Komárek J, Komárkowa J, 2006. Diversity of Aphanizomenonlike cyanobacteria. Diverzitasinic z okruhu rodu Aphanizomenon. Czech Phycology. Olomouc. 6:1-32.

Komárek J, Zapomèlova E, 2007. Planktic morphospecies of the cyanobacterial genus Anabaena $=$ subg. Dolichosperum - 1 . part: coiled types. Fottea. Olomouc. 7:1-31.

Komárek J, Zapomèlova E, 2008. Planktic morphospecies of the cyanobacterial genus Anabaena=subg. Dolichosperum - 2 . Part: straight types. Fottea. Olomouc. 8:1-14.

Kovach WL, 2010. MVSP - A MultiVariate Statistical Package for Windows, ver. 3.2 Kovach Computing Services, Pentraeth, UK: $112 \mathrm{pp}$.

Krammer K, Lange-Bertalot H, 1986. [Bacillariophyceae. 1. Teil: Naviculaceae, p. 1-876]. In: In: H. Ettl, J. Gerloff, H. Heynig and D. Mollenhauer (eds.), Süsswasserflora von Mitteleuropa, Bd. 2/1].[Book in German]. Gustav Fischer Verlag.

Krammer K, Lange-Bertalot H, 1988. [Bacillariophyceae. 2. Teil: Bacillariaceae, Epithemiaceae, Surirellaceae, p. 1-796]. In: H. Ettl, G. Gärtner, J. Gerloff, H. Heynig and D. Mollenhauer (eds.), [Süsswasserflora von Mitteleuropa, Bd. 2/2].[Book in German].Gustav Fischer Verlag.

Krammer K, Lange-Bertalot H, 1991a. [Bacillariophyceae. 3. Teil: Centrales, Fragilariaceae, Eunotiaceae, p. 1-578]. In: H. Ettl, G. Gärtner, J. Gerloff, H. Heynig and D. Mollenhauer (eds.), [Süsswasserflora von Mitteleuropa, Bd. 2/3].[Book in German].Gustav Fischer Verlag.

Krammer K, Lange-Bertalot H, 1991b. [Bacillariophyceae. 4. Teil: Achnanthaceae, Ktitische Ergänzungen zu Navicula (Lineolatae) und Gomphonema Gesamtliteraturverzeichnis, p. 1-437]. In: H. Ettl, G. Gärtner, J. Gerloff, H. Heynig and D. Mollenhauer (eds.), [Süsswasserflora von Mitteleuropa, Bd. 2/4].[Book in German]. Gustav Fischer Verlag.

Krasznai E, Borics G, Várbíró G, Abonyi A, Padisák J, Deák C, Tóthmérész B, 2010. Characteristics of the pelagic phytoplankton in shallow oxbows. Hydrobiologia 639:173-184.

Kuczyńska-Kippen N, Nagengast B, 2006. The influence of the spatial structure of hydromacrophytes and differentiating habitat on the structure of the rotifer and cladoceran community. Hydrobiologia 559:203-212.

Lair N, 2006. Abiotic vs. biotic factors: lessons drawn from rotifers in the Middle Loire a meandering river monitored from 1995 to 2002, during low flow periods. Hydrobiologia 546:57-472.

Lake PS, Bond NR, 2007. Australian futures: freshwater ecosystems and human water usage. Future 39:288-305.

Lauridsen TL, Pedersen LJ, Jeppesen E, Søndergaard M, 1996. The importance of macrophyte bed size for cladoceran composition and horizontal migration in a shallow lake. J. Plankton Res. 18:2283-2294.

Makowski J, 1998. [The lower Vistula River and its bunds. The historical development and the current state and maintenance during major floods. Part Two: The section from Torun to Biała Góra].[Book in Polish]. Instytut Budownictwa Wodnego PAN Biblioteka Naukowa Hydrotechnika: 78 pp.

Marneffe Y, Descy JP, Thome JP, 1996. The zooplankton of the lower river Meuse, Belgium: seasonal changes and impact of industrial and municipal discharges. Hydrobiologia 319:1-13.

Melo S, Huszar VLM, 2000. Phytoplankton in an Amazonian flood-plain lake (Lago-Batata, Brasil): diel variation and species strategies. J. Plankton Res. 22:63-76.

Meschiatti AJ, Arcifa MS, Fenerich-Verani N, 2000. Fish community associated with macrophytes in Brazilian floodplain lakes. Environ. Biol. Fish. 58:33-143.

Mihaljević M, Stević F, Horvatić J, Hackenberger-Kutuzović B, 2009. Dual impact of the flood pulses on the phytoplankton assemblages in a Danubian floodplain lake (Kopački Rit Nature Park, Croatia). Hydrobiologia 618:77-88.

Napiórkowski P, 2009. Influence of hydrological conditions on zooplankton of oxbow lakes (old riverbeds) of the Lower Vistula in the city of Toruń. Limnol. Pap. 4:55-67.

Napiórkowski P, Napiórkowska T, 2014. The impact of catastrophic flooding on zooplankton. Pol. J. Environ. Stud. 23:409-417.

Nogrady T, Wallance RL, Snell TW, 1993. Rotifera, biology, ecology and systematic. 4. SPB Acad. Publ.: 142 pp.

Nusch EA, 1980. Comparison of different methods for chlorophyll and phaeopigment. Arch. Hydrobiol. 14:14-16.

Obolewski K, 2011. Composition and density of plant - associated invertebrates in relation to environmental gradients and hydrological connectivity of wetlands. Ocean. Hydrobiol. Stud. 40: 52-63.

Padisák J, Borics G, Fehér G, Grigorszky I, Oldal I, Schmidt A, Zámbóné-Doma Z, 2003. Dominant species, functional assemblages and frequency of equilibrium phases in late summer phytoplankton assemblages in Hungarian small shallow lakes. Hydrobiologia 502:157-168.

Padisák J, Crossetti LO, Naselli-Flores L, 2009. Use and misuse in the application of the phytoplankton functional classification: a critical review with updates. Hydrobiologia 621:1-19. 
Paira AR, Drago EC, 2007. Origin, evolution and types of floodplain water bodies, p. 53-80. In: M.H. Iriondo, J.C. Paggi and M.J. Parma (eds.), The middle Paraná River: limnology of subtropical wetlands. Springer-Verlag.

Pithart D, Pichlová R, Bílý M, Hrbáček J, Novotná K, Pechar L, 2007. Spatial and temporal diversity of small shallow waters in river Lužnice floodplain. Hydrobiologia 584:265-275.

Popovskỳ J, Pfiester LA, 1990. [Dinophyceae (Dinoflagellida), p. 1-272]. In: H. Ettl, J. Gerloff, H. Heynig and D. Mollenhauer (eds.), Süßwasserflora von Mitteleuropa, Bd. 6. Gustav Fischer Verlang.

Radwan S, 2004. [Polish Freshwater Fauna: 32A and 32B. Wrotki. Rotifera].[Book in Polish]. Tercja Press Łódź: 447 pp.

Redford KH, Richter BD, 1999. Conservation of biodiversity in a world of use. Conserv. Biol. 13:1246-1256.

Reynolds CS, Huszar V, Kruk C, Naselli-Flores L, Melo S, 2002. Towards a functional classification of the freshwater phytoplankton. J. Plankton Res. 24:417-428.

Růžička J, 1977. [Die Desmidiaceen Mitteleuropas, Bd. 1/1]. [Book in German]. E. Schweizerbart'sche Verlagsbuchhandlung: $336 \mathrm{pp}$.

Rybak JI, Błędzki LA, 2010. [Freshwater planktonic Crustacea].[Book in Polish]. WUW Warsaw: 365 pp.

Salbrechter M, 1998. Changes in the zooplankton community during restoration of a shallow lake in Vienna, Austria. In: N. Walz and B. Nixdorf (eds.) Proceeding Int. Conf. Shallow Lakes '98 on trophic interactions in shallow freshwater and brackish waterbodies. Blossin near Berlin.

Scheffer M, 1998. Ecology of shallow lakes. Kluwer: 357 pp.

Schöll K, 2009. Diversity of planktonic rotifer assemblages in the water bodies of the Gemenc floodplain (Duna-Drava National Park, Hungary). Biol. B 64:951-958.

Shiel RJ, Green JD, Nielsen DL, 1998. Floodplain biodiversity: why are there so many species? Hydrobiologia 387/ 388:39-46.

Spaink PA, Ietswaart T, Roijackers R, 1998. Plankton dynamics in a dead arm of the river Waal: a comparison with the main channel. J. Plankton Res. 20:1997-2007.
Starmach K, 1968. [Chrysophyta I. Chrysophyceae - złotowiciowce oraz wiciowce bezbarwne - zooflagellata wolnożyjące. 5].[Book in Polish]. Państwowe Wydawnictwo Naukowe: 598 pp.

Starmach K, 1974. [Cryptophyceae - kryptofity, Dinophyceae - dinofity, Raphiophyceae - rafidofity. 4].[Book in Polish]. Państwowe Wydawnictwo Naukowe: 520 pp.

Starmach K, 1983. [Euglenophyta - eugleniny. 3].[Book in Polish]. Państwowe Wydawnictwo Naukowe: 594 pp.

Starmach K, Wróbel S, Pasternak K, 1976. [Hydrobiologia, limnologia].[Book in Polish]. PWN Warszawa: 620 pp.

Thomaz SM, Bini LM, Bozelli RL, 2007. Floods increase similarity among aquatic habitats In River-floodplain systems. Hydrobiologia 579:1-13.

Tockner K, Robinson ChT, Uehlinger URS, 2009. Rivers of Europe. Elsevier: 699 pp.

Utermöhl H, 1958. [Zur Vervollkommnung der quantitative Phytoplankton Methodik].[Article in German]. Mitt. Int. Ver. Theor. Angew. Limnol. 9:1-38.

Wojciechowska W, Paszteleniec A, Solis M, 2007. Diversity and dynamics of phytoplankton in floodplain lakes (Bug River, eastern Poland) Ocean. Hydrobiol. Stud. 36(Suppl.1):199-208.

Wołowski K, 1998. Taxonomic and Environmental studies on Euglenophytes of the Kraków-Częstochowa Upland (Southern Poland). Fragmenta Floristica et Geobotanica, Supplementum 6. W. Szafer Institute of Botany Polish Academy of Sciences: $192 \mathrm{pp}$.

Wołowski K, Hindák F, 2003. Atlas of Euglenophytes. Veda, Publishing House of the Slovak Academy of Sciences: $135 \mathrm{pp}$.

van Dijk GM, van Zanten B, 1995. Seasonal changes in zooplankton abundance in the lower Rhine during 1987-1991. Hydrobiologia 304:29-38.

Vadadi-Fülöp Cs, 2009. Zooplankton (Cladocera, Copepoda) dynamics in the River Danube upstream and downstream of Budapest, Hungary. Opusc. Zool. 40:87-98

Vadadi-Fülöp Cs, Hufnagel L, Jablonszky G, Zsuga K, 2009. Crustacean plankton abundance in the Danube River and its side arms in Hungary. Biologia 64:1184-1195. 